\title{
Carbon Sequestration in Dominant Soil Series under Different Land Uses of Tamil Nadu, India
}

\author{
A. C. Surya Prabha ${ }^{1 *}$, K. Arulmani ${ }^{1}$, M. Senthivelu ${ }^{2}$, R. Velumani ${ }^{1}$ and K. S. Rathnam ${ }^{1}$ \\ ${ }^{1}$ Silviculture and Forest Management Division, Institute of Forest Genetics and Tree \\ Breeding, Coimbatore-641 002, Tamil Nadu, India \\ ${ }^{2}$ Department of Millets, Tamil Nadu Agricultural University, Coimbatore-641 003, \\ Tamil Nadu, India \\ *Corresponding author
}

\begin{tabular}{|l|}
\hline Ke y w o r d s \\
Carbon sequestration, \\
$\begin{array}{l}\text { Land use, Soil series, } \\
\text { Organic carbon stock }\end{array}$ \\
\hline Article Info \\
\hline $\begin{array}{l}\text { Accepted: } \\
\text { 22 July 2019 } \\
\text { Available Online: } \\
\text { 10 August } 2019\end{array}$ \\
\hline
\end{tabular}

\section{Introduction}

Investigations on Soil organic carbon (SOC) is gaining attention worldwide due to the potential of the soil to become a manageable sink for atmospheric carbon dioxide and thus to mitigate climate change and the known benefits of increased soil organic carbon for the functioning of soils (Mc Bratney et al.,
2014). The amount of carbon stored in soil organic matter is one of the largest and most dynamic reservoirs of carbon in the global cycle. Soil organic carbon (SOC) is the largest terrestrial pool of sequestered carbon (Batjes, 1996; Chhabra et al., 2003) and therefore plays a pivotal role in global $\mathrm{C}$ dynamics. The role of soils and SOC in climate change adaptation and mitigation has been widely 
recognized and validated in various studies, both experimentally and through modelling (Scharlemann et al., 2014). The amount of carbon stored in soil organic matter is one of the largest and most dynamic reservoirs of carbon in the global cycle. Soil organic carbon (SOC) has an important influence on the physical and chemical properties of the soils and it can release nutrients through mineralization in forms available to plants (Lal, 2011). The carbon balance of terrestrial ecosystems can be changed markedly by the impact of human activities, including deforestation, biomass burning and land-use change, which result in the release of trace gases that enhance the greenhouse effect (Bhattacharya et al., 2000). Absorbing $\mathrm{CO}_{2}$ from the atmosphere and moving into the physiological system and biomass of the plants, and finally into the soil is the only practical way of removing large volumes of the major greenhouse gas $\left(\mathrm{CO}_{2}\right)$ from the atmosphere into the biological system.

Soils host the largest terrestrial carbon pool (Scharlemann et al., 2014) and play a crucial role in the global carbon balance by regulating dynamic bio-geochemical processes and the exchange of greenhouse gases (GHG) with the atmosphere (Lal, 2013). In the presence of climate change, land degradation and biodiversity loss, soils have become one of the most vulnerable resources in the world (FAO and ITPS, 2015). Globally, Soil Organic Carbon (SOC) stocks are estimated at an average of $1,500 \pm 230 \mathrm{Pg} \mathrm{C}$ in the first meter of soil, which is nearly twice as much as atmospheric carbon (828 $\mathrm{Pg} \mathrm{C}$ ) and thrice as that of terrestrial vegetation (500 Pg C) (Quere et al., 2016). Thus, any change in soil carbon pool would have a significant effect on the global carbon budget. As an indicator for soil health, SOC is important for its contributions to food production, mitigation and adaptation to climate change, and the achievement of the Sustainable Development Goals (SDGs).
Given the role of soils in climate change mitigation and adaptation, judicious soil management needs to be implemented to ensure that soil is rendered a sink rather than a source for atmospheric $\mathrm{CO}_{2}$ (Paustian et al., 2016). Therefore, it is ideal to study and determine, for any given ecosystem, the current SOC stocks to determine a soil's carbon sequestration potential. The Intergovernmental Panel on Climate Change identified creation and strengthening of carbon sinks in the soil as a clear option for increasing removal of $\mathrm{CO}_{2}$ from the atmosphere and has recognized soil organic carbon pool as one of the five major carbon pools for the Land Use, Land Use Change in Forestry (LULUCF) sector.

Estimating $\mathrm{C}$ pools under existing land uses provides baseline data to project $\mathrm{C}$ sequestration over time. Enhanced sequestration of atmospheric $\mathrm{CO}_{2}$ in the soil, ultimately as stable soil organic matter, provides a more lasting solution than sequestering $\mathrm{CO}_{2}$ in standing biomass. Hence, accurate quantification of soil organic carbon is necessary for detection and prediction of changes in response to changing global climate. Soils of the world are potentially viable sinks for atmospheric carbon and may significantly contribute to the mitigation of global climate change (Lal, 1998; Bajracharya et al., 1998b; Singh, 2005; Venkanna et al., 2014). It is necessary to have a good knowledge of the current global SOC stock and its spatial distribution to inform various stakeholders (e.g. farmers and policymakers) to make the best use of available land and provide the best opportunities to mitigate and adapt to climate change, but also ensure sufficient food production and water supply. Comparative studies on assessment of soil organic carbon stock in dominant soil series under different land use in Tamil Nadu are lacking. Therefore, this study was undertaken to assess carbon stock in dominant soil series 
under different land use systems in the NorthEastern Agro-climatic zone of Tamil Nadu.

\section{Materials and Methods}

The study was conducted in the North-Eastern Agro-climatic zone of Tamil Nadu. Tamil Nadu state is classified into seven agroclimatic zones, based on rainfall distribution, irrigation pattern, soil characteristics, cropping pattern and other physical, ecological and social characteristics (Anon, 1993). The North-Eastern zone covers the districts of Thiruvallur, Kancheepuram, Cuddalore (excluding Chidambaram and Kattumanarkovil taluks), Villupuram, Thiruvannaamalai, Vellore and parts of Perambalur and Ariyalur and is located between $18^{\circ} 5^{\prime}$ and $13^{\circ} 2^{\prime}$ of North latitude and $76^{\circ} 15^{\prime}$ and $80^{\circ} 22^{\prime}$ 'East longitude. It is spread over an area of 31065 sq. km. which is $23.9 \%$ of the state's total area. Soil samples (96 nos.) belonging to Arasanatham and Kadambady soil series were collected from various land uses viz., Agriculture, Agroforestry, Plantation and Forest. Soil samples were collected from three plots and at four depths viz., 0-30, 30-50, 50-80 and 80-100 cm from the North-Eastern Agro-climatic zone of Tamil Nadu.

The design adopted was Factorial Randomized Block Design (FRBD). The soil samples collected from representative fields' with three replications were then air-dried, mixed well and passed through a $2 \mathrm{~mm}$ sieve for the analysis of selected soil physical and chemical properties. At each sampling point, an area of $0.5 \mathrm{~m} \times 0.5 \mathrm{~m}$ was removed and a pit of $30 \mathrm{~cm}$ wide, $50 \mathrm{~cm}$ in length and $100 \mathrm{~cm}$ deep was dug. The soil was scrapped from three sides of the pit with the help of a kurpee at each depth. The soil was mixed thoroughly and transferred to a polythene bag with proper labelling. Latitude, longitude and altitude of each sampling point were recorded by GPS.
In the laboratory, the soil samples were manually fractionated into three aggregate size classes viz., macro-aggregates $(250-2000 \mu \mathrm{m})$, micro-aggregates $(53-250 \mu \mathrm{m})$ and silt and clay sized fraction $(<53 \mu \mathrm{m})$ according to the procedure from Six et al., (2002). The soil sample was submerged in de-ionized water for about five minutes and then placed on top of $250 \mu \mathrm{m}$ sieve to release the air that is trapped inside soil pores. The sieving was done manually. The fraction remaining on the top of a $250 \mu \mathrm{m}$ sieve was collected in a hard plastic pan and allowed to oven-dry at $65^{\circ} \mathrm{C}$ and weighed. Water plus soil $<250 \mu \mathrm{m}$ was poured through a $53 \mu \mathrm{m}$ sieve and the same sieving procedure was repeated. The overall procedure yielded a water-stable, macro-sized fraction 250-2000 $\mu \mathrm{m}$; a micro-sized fraction 53-250 $\mu \mathrm{m}$, and silt+clay sized $<53 \mu \mathrm{m}$ fraction. The fractionated soil samples were used for the estimation of organic carbon. The total number of soil samples analyzed after fractionation was 288. Soil organic carbon was estimated by standard Chromic acid wet oxidation method of Walkley and Black (1934). Organic matter in the soil was oxidized with the mixture of potassium dichromate and concentrated sulphuric acid, utilizing the heat of dilution of sulphuric acid. Unused potassium dichromate was back titrated with ferrous ammonium sulphate. For the estimation of bulk density, two to three clods of $2 \mathrm{~mm}$ size were collected from each pit and bulk density was estimated by the wax coating (clod) method. The clods were wrapped in cotton and placed in plastic containers to avoid breakage during transportation of the clods to the laboratory. In the laboratory, the clods were tied with a thread and dipped in molten wax to coat the clod surface. The wax coated clod was dipped in water and the bulk density was determined from the volume of water displaced. The per cent of coarse fragments was quantified by visual observation of the area occupied by coarse fragments. Soil organic carbon stock 
was calculated by equation as suggested by IPCC Good Practice Guidelines for LULUCF (2003).

$\begin{aligned} \text { Horizon=n } & \text { Horizon=n } \\ \text { SOC }=\sum \text { SOC } & =\sum([S O C] \quad * \text { Bulk density * Depth * }(1-C \text { frag }) * \text { 100 }) \\ \text { Horizon=1 } & \text { Horizon=1 }\end{aligned}$

Where,

SOC $=$ Representative soil organic carbon content for the forest type and soil of interest, tonnes $\mathrm{Cha}^{-1}$.

SOC = Soil organic carbon content for $\mathrm{a}$ constituent soil horizon, tonnes $\mathrm{C} \mathrm{ha}^{-1}$

[SOC $]=$ Concentration of SOC in a given soil mass obtained from analysis, $\mathrm{g} \mathrm{C}(\mathrm{kg} \text { soil })^{-1}$

Bulk density $=$ Soil mass per sample volume, tonnes soil $\mathrm{m}^{-3}$ (equivalent to $\mathrm{Mg} \mathrm{m}^{-3}$ )

Depth $=$ Horizon depth or thickness of soil layer, $\mathrm{m}$

$\mathrm{C}$ frag $=\%$ volume of coarse fragments $/ 100$, dimensionless.

\section{Statistical analysis}

All statistical tests were performed with SPSS (®) 19.0 version statistical software. Wherever the treatment differences were found significant, the critical differences were worked out at 5 per cent probability and values were furnished. The treatment differences that are non-significant were indicated as Non-Significant (NS).

\section{Results and Discussion}

Soil organic carbon (SOC) is one of the largest and most dynamic reservoirs of carbon in the global carbon cycle. Soil organic carbon stock under different land uses in macro-sized fraction, micro-sized fraction and silt+clay sized fraction is presented in Tables 1, 2 and 3 . The variation of SOC stock under different land uses was significantly prominent at different soil depths and the total soil organic carbon (SOC) stock varied significantly among the selected land -use types. In Arasanatham series, the highest SOC stock was recorded under forest land use $(78.3 \mathrm{Mg}$ $\left.\mathrm{ha}^{-1}\right)$ in the silt +clay sized fraction $(<53 \mu \mathrm{m})$ and the agriculture land use $\left(21.3 \mathrm{Mg} \mathrm{ha}^{-1}\right)$ the lowest SOC stock at 0-30 cm soil depth.

With increasing soil depth, SOC stock was found to decrease. Similar trend was observed in Kadambady series also, where, maximum soil organic carbon stock was registered under forest land use (56.2 $\mathrm{Mg} \mathrm{ha}^{-1}$ ) in macro-sized fraction, micro-sized fraction $\left(57.6 \mathrm{Mg} \mathrm{ha}^{-1}\right)$ and silt+clay sized fraction $\left(58.2 \mathrm{Mg} \mathrm{ha}^{-1}\right)$ at 0-30 cm depth followed by agro-forestry and plantation (Fig. 1, 2 and 3). While comparing the different soil fractions, maximum SOC was retained in the silt+clay sized fraction (< $53 \mu \mathrm{m})$ in all the land uses. Soil organic carbon in the silt+clay sized fraction was highest under forest soils followed by plantation, agro-forestry and agriculture land use.

The study showed a higher soil organic carbon (SOC) stock under forest land use at $0-30 \mathrm{~cm}$ depth in the two dominant soil series viz. Arasanatham and Kadambady of the NorthEastern agro-climatic zone. This was followed by agro-forestry, plantation and agriculture land uses. The higher amount of organic carbon in forest system may be because of higher leaf litter and the extensive root system of forest trees (Mandal et al., 2005; Koppad and Tikhile, 2014). The total amount of organic carbon in the soil can be considered as a measure of stored organic matter. Agriculture systems recorded the lowest soil organic carbon content and stocks. 
Table.1 Soil organic carbon stock $\left(\mathrm{Mg} \mathrm{ha}^{-1}\right)$ in Arasanatham series $(250-2000 \mu \mathrm{m})$

\begin{tabular}{|l|c|c|c|c|c|}
\hline \multirow{2}{*}{ Land use } & \multicolumn{4}{|c|}{ Soil Depth (cm) } & \multirow{2}{*}{ Mean } \\
\cline { 2 - 5 } & $\mathbf{0 - 3 0}$ & $\mathbf{3 0 - 5 0}$ & $\mathbf{5 0 - 8 0}$ & $\mathbf{8 0 - 1 0 0}$ & \\
\hline Agriculture & 15.4 & 14.3 & 12.8 & 15.4 & 14.5 \\
\hline Plantation & 17.4 & 16.3 & 15.9 & 12.2 & 15.5 \\
\hline Agro forestry & 35.4 & 36.5 & 33.3 & 21.7 & 31.7 \\
\hline Forest & 76.0 & 63.1 & 55.1 & 51.3 & 61.4 \\
\hline \multicolumn{1}{|c|}{ Mean } & 36.1 & 32.6 & 29.3 & 25.2 & \\
\hline \multirow{4}{*}{} & Factor & SE(d) & CD (0.05\%) & \\
\cline { 2 - 5 } & Land use & 1.35 & 2.75 & \\
\cline { 2 - 5 } & Soil Depth & 1.35 & 2.75 & \\
\cline { 2 - 5 } & L x D & 2.69 & 5.49 & \\
\cline { 2 - 5 } & & & & \\
\end{tabular}

Table.2 Soil organic carbon stock $\left(\mathrm{Mg} \mathrm{ha}^{-1}\right)$ in Arasanatham series $(53-250 \mu \mathrm{m})$

\begin{tabular}{|c|c|c|c|c|c|c|}
\hline \multirow{2}{*}{\multicolumn{2}{|c|}{ Land use }} & \multicolumn{4}{|c|}{ Soil Depth (cm) } & \multirow[t]{2}{*}{ Mean } \\
\hline & & $0-30$ & $30-50$ & $50-80$ & $80-100$ & \\
\hline \multicolumn{2}{|c|}{ Agriculture } & 16.5 & 15.8 & 14.0 & 13.7 & 15.0 \\
\hline \multicolumn{2}{|l|}{ Plantation } & 18.7 & 16.9 & 16.3 & 9.0 & 15.2 \\
\hline \multicolumn{2}{|c|}{ Agro forestry } & 40.1 & 38.5 & 34.4 & 23.7 & 34.2 \\
\hline \multicolumn{2}{|l|}{ Forest } & 76.8 & 67.8 & 53.8 & 52.0 & 62.6 \\
\hline \multicolumn{2}{|l|}{ Mean } & 38.0 & 34.8 & 29.6 & 24.6 & \\
\hline & & actor & $\mathrm{SE}(\mathrm{d})$ & \multicolumn{2}{|c|}{ CD (0.05\%) } & \\
\hline & \multicolumn{2}{|c|}{ and use } & 1.39 & \multicolumn{2}{|c|}{2.83} & \\
\hline & \multicolumn{2}{|c|}{ oil Depth } & 1.39 & \multicolumn{2}{|c|}{2.83} & \\
\hline & \multicolumn{2}{|c|}{ L X D } & 2.77 & \multicolumn{2}{|c|}{5.66} & \\
\hline
\end{tabular}

Table.3 Soil organic carbon stock $\left(\mathrm{Mg} \mathrm{ha}^{-1}\right)$ in Arasanatham series $(<53 \mu \mathrm{m})$

\begin{tabular}{|c|c|c|c|c|c|}
\hline \multirow[t]{2}{*}{ Land use } & \multicolumn{4}{|c|}{ Soil Depth $(\mathrm{cm})$} & \multirow[t]{2}{*}{ Mean } \\
\hline & 0-30 & $30-50$ & $50-80$ & 80-100 & \\
\hline Agriculture & 21.3 & 18.4 & 20.4 & 20.6 & 20.2 \\
\hline Plantation & 21.2 & 18.8 & 17.8 & 13.9 & 17.9 \\
\hline Agro forestry & 50.6 & 40.1 & 35.5 & 26.8 & 38.3 \\
\hline Forest & 78.3 & 69.3 & 56.7 & 55.8 & 65.0 \\
\hline \multirow[t]{5}{*}{ Mean } & 42.9 & 36.7 & 32.6 & 29.3 & \\
\hline & Factor & SE(d) & \multicolumn{2}{|c|}{ CD $(0.05 \%)$} & \\
\hline & Land use & 1.50 & \multicolumn{2}{|c|}{3.07} & \\
\hline & Soil Depth & 1.50 & \multicolumn{2}{|c|}{3.07} & \\
\hline & $L \times D$ & 3.00 & \multicolumn{2}{|c|}{6.13} & \\
\hline
\end{tabular}




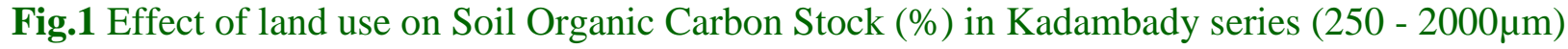

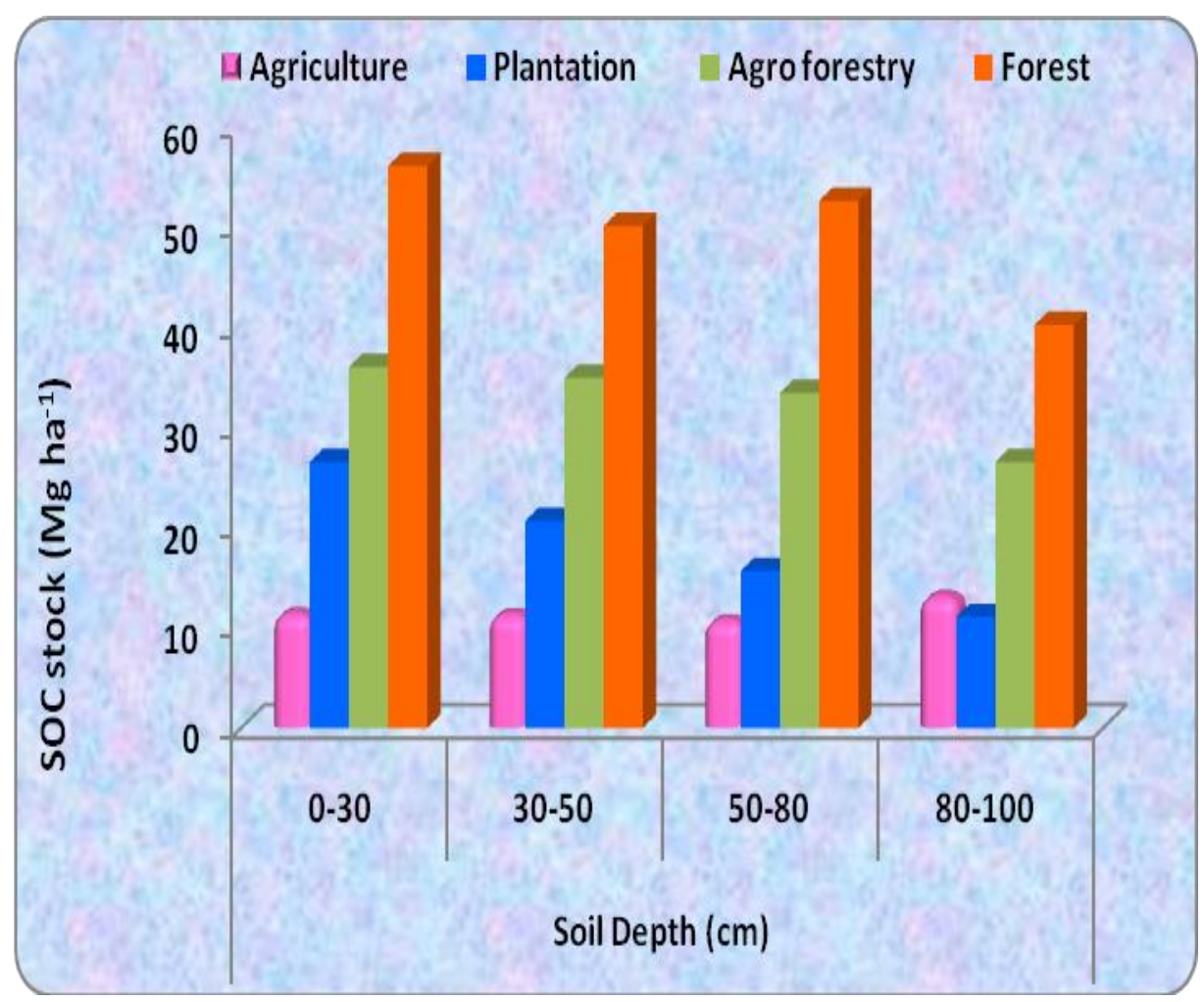

Fig.2 Effect of land use on Soil Organic Carbon Stock (\%) in Kadambady series (53 - $250 \mu \mathrm{m})$

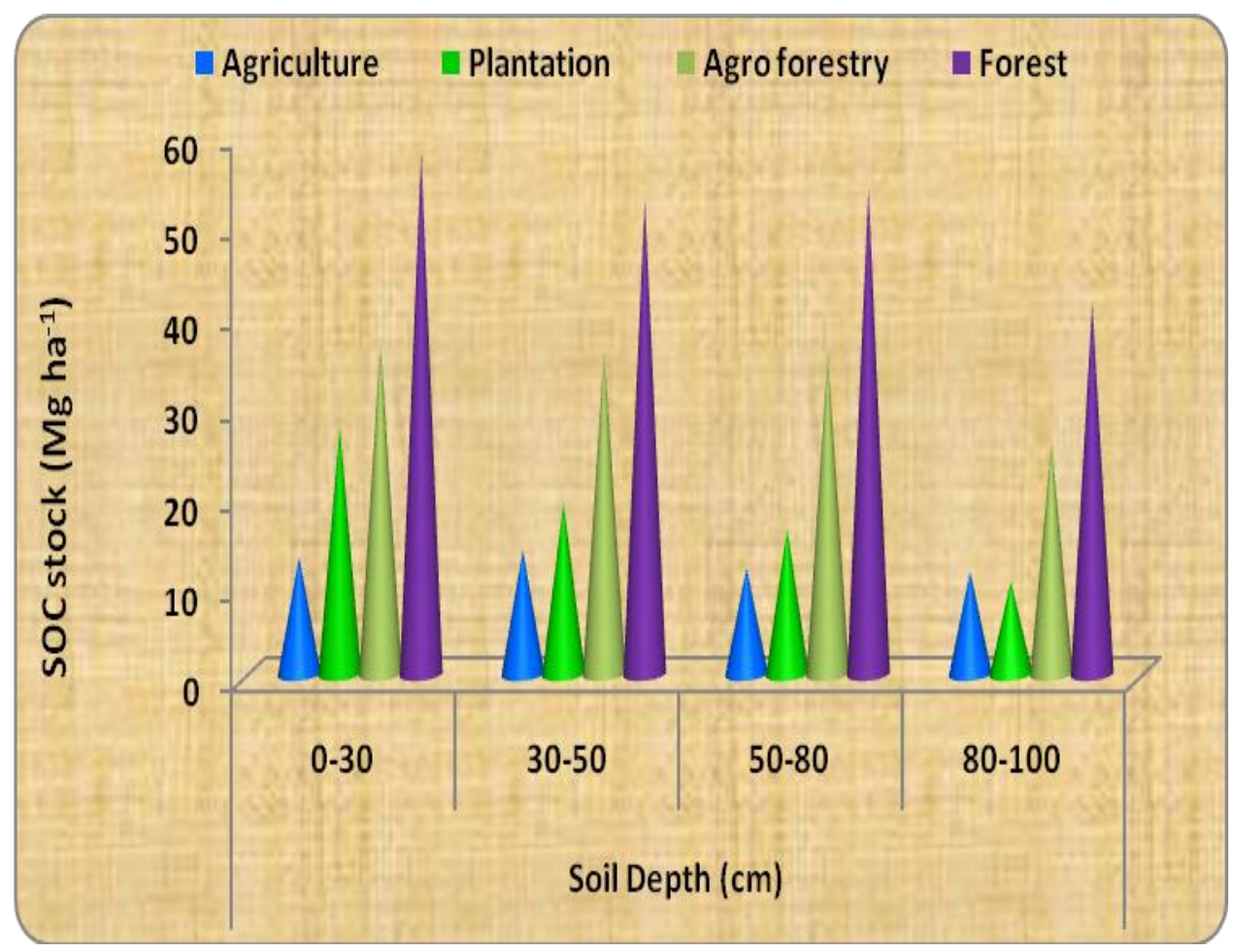


Fig.3 Effect of land use on Soil Organic Carbon Stock (\%) in Kadambady series $(<53 \mu \mathrm{m})$

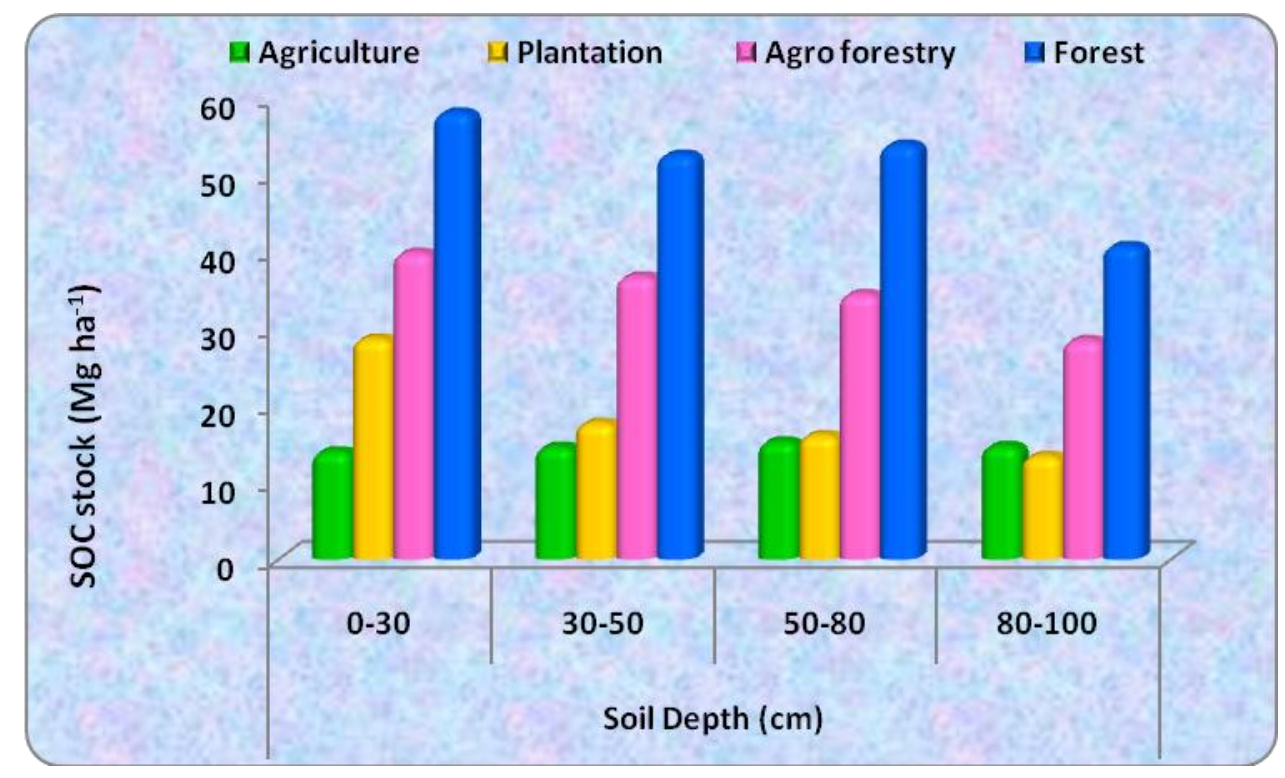

Tillage leads to the mechanical breakdown of the soil aggregates resulting in loss of carbon that was once encapsulated within the aggregates, whereas minimization of the soil disturbance leads to carbon accumulation (Bhattacharya, 2001). It is an established fact that intensive agriculture will result in decreased amount of soil organic carbon (Manjaiah et al., 2010). The present study also revealed the same trend. Less amount of organic carbon under cultivated land might be due to the effects of tillage practices coupled with reduced soil organic matter inputs and apparently complete removal of crop residues from cultivated fields (Adeboye et al., 2011). As expected, the soil organic carbon content decreased with soil depth under all land-uses. Furthermore, SOC contents by depth in all land use systems were related to the silt + clay sized fraction, as reported in a previous study (Takimoto et al., 2008a).

In the present investigation, among the different soil fractions, maximum SOC was retained in the silt+clay sized fraction $(<53$ $\mu \mathrm{m})$ in all the land uses. The macro-sized fraction class $(250-2000 \mu \mathrm{m})$ represents the macroaggregates that contain the more active pool of carbon, which is influenced by the land-use and soil management (Six et al., 2002). This pool contains the recent carbon depositions in soil (Carter, 1996); therefore, it is sensitive to changes in organic matter dynamics with time. The micro-sized class (53-250 $\mu \mathrm{m})$ represents the microaggregates is the building block of soil structure and more stable in storing carbon (Tiessen and Stewart, 1983). Organic carbon in this class has lower decomposition rate and can store carbon for a longer time than in larger size fractions (Six et al., 2000). The SOC content in silt and clay sized fraction $(<53 \mu \mathrm{m})$ is considered to be more stable than in larger soil fractions (Six et al., 2002). The SOC content in silt+clay sized fraction $(<53 \mu \mathrm{m})$ showed a clear trend of increasing amount with increasing tree density, with the lower content in the agriculture land use and higher content in the forest soils. Similar studies reported by Saha et al., (2010) revealed that a higher amount of carbon was stored in the silt and clay sized fraction in forest soils and small-sized home gardens.

Soil contains a active pool of carbon that plays a vital role in the global carbon cycle. 
As sequestration of atmospheric $\mathrm{CO}_{2}$ in soils is an option to reduce global warming, baseline data and information on SOC storage are essential for characterizing carbon dynamics. The study has enabled generation of baseline data on the soil organic carbon under different land uses in the dominant soil series of Tamil Nadu. The data generated in the present study would serve as a base for future research on climate change mitigation. The user groups viz., farmers will have added benefit in identifying the most suitable land use for enhancing storage of soil organic carbon thereby improving yields of crops and trees.

\section{Acknowledgement}

We are thankful to Director General, Indian Council of Forestry Research and Education, Dehradun for providing financial support to undertake the project work.

\section{References}

Adeboye, M.K.A, AbdullahiBala, Akim O, Osunde, Anthony, O, Uzoma, AyoJ. Odofin and Baba A. Lawal. 2011. Assessment of soil quality using soil organic carbon and total nitrogen and microbial properties in tropical agro ecosystems'. Agricultural Sciences, 2 (1):34-40.

Anon. 1993. 'Manual on Agroforestry in dry lands'. Directorate of Agriculture, Madras600005.

Bajracharya, R.M., Lal, R. and Kimble, J.M. 1998b. Soil organic carbon distribution in aggregates and primary particle fractions as influenced by erosion phases and landscape position. In: Lal, R., Kimble, J.M., Follett, R.F. and Stewart, B.A. eds. Soil processes and the carbon cycle. CRC Press, Boca Raton, Florida, USA, pp.353-367.

Bhattacharya, R.M. 2001. Land preparation: an integral part of farming system in the midhills of Nepal. Nepal Journal of Science and Technology, 3:15-24.

Bhattacharya, T., Pal, D.K., Mandal, C. and
Velayutham, M. 2000. Organic carbon stock in Indian soils and their geographical distribution. Current Science, 79:655-660.

Carter, M.R. 1996. Analysis of soil organic matter in agro-ecosystems. In: Carter, M.R., Stewart, B.A. (eds). Structure and organic matter storage in agricultural soil. CRC Press, Boca Raton, pp.3-11.

FAO and ITPS. 2015. Status of the World's Soil Resources (SWSR) - Technical Summary. Food and Agriculture Organization of the United Nations and Intergovernmental Technical Panel on Soils, Rome, Italy.

IPCC. 2003. Good Practice Guidance for Land Use, Land Use Change and Forestry. Published by the Institute for Global Environmental Strategies (IGES) for the IPCC. Publishers Institute for Global Environmental Strategies, Japan.

Koppad, A.G. and Tikhile, P. 2014. Role of forest on carbon sequestration in soils of Joida and Karwar taluka of Uttarakannada district. Indian Forester, 140(3): 260-264.

Lal R. 2011. Sequestering carbon in soils of agroecosystems. Food Policy, 36:33-39.

Lal, R. 1999. Global carbon pools and fluxes and the impact of agricultural intensification and judicious land use. In: Prevention of land degradation, enhancement of carbon sequestration and conservation of biodiversity through land use change and sustainable land management with a focus on Latin America and the Caribbean. World Soil Resources Report 86. FAO, Rome. p 45-52.

Lal. 2013. Soil carbon management and climate change. http://dx.doi.org/10.4155/cmt.13.31

Mandal, U.K., Ramesh, V., Sharma, K.L., Ramachandran, K. and Victor, U.S. 2005. Tension infiltration for estimating pore distribution of Alfisols under different land management. J. Indian Soc. Soil Sci., 53(3): 296-301.

Manjaiah, K.M., Sarvendra Kumar, M.S., Sachdev, P., Sachdev and Datta, S.C. 2010. Study of Clay - Organic Complexes. Current Science, 98(7): 915-921.

Mc Bratney, Alex, B., Uta Stockmann, Denis, A. Angers, Budiman Minasny and Damien, J. 2014. Challenges for soil organic carbon research, Progress in Soil Science. Springer 
International Publishing, pp.3-16.

Paustian, K., Lehmann, J., Ogle, S., Reay, D., Robertson, G. P. \& Smith, P. 2016. Climate-smart soils. Nature, 532(7597): 4957.

Quéré, C., Andrew, R. M., Canadell, J. G., Sitch, S., Korsbakken, J. I., Peters, G. P., Manning, A. C., Boden, T. A., Tans, P. P., Houghton, R. A., Keeling, R. F., Alin, S., Andrews, O. D., Anthoni, P., Barbero, L., Bopp, L., Chevallier, F., Chini, L. P., Ciais, P., Currie, K., Delire, C., Doney, S. C., Friedlingstein, P., Gkritzalis, T., Harris, I., Hauck, J., Haverd, V., Hoppema, M., Goldewijk, K. K., Jain, A. K., Kato, E., Wiltshire, A. J. \& Zaehle, S. 2016. Global Carbon Budget 2016. Earth System Science Data, 8: 605-649.

Saha, S.K., Nair, P.K.R., Nair, V.D. and Kumar, B.M. 2010. Carbon storage in relation to soil size fractions under tropical tree based land use systems. Plant Soil, 328: 433-446.

Scharlemann et al., 2014. Global soil carbon: understanding and managing the largest terrestrial carbon pool. http://www.tandfonline.com/doi/abs/10.415 5/cmt.13.77

Singh, G. 2005. Carbon sequestration under an agrisilvicultural system in the arid region. Indian Forester, 131(4): 543-552.

Six, J, Conant, R.T, Paul, E.A. and Paustian, K. 2002. Stabilization mechanisms of soil organic matter: Implications for C- saturation of soils. Plant and Soil, 241: 155176.

Six,J., Elliot, E.T., and Paustian, K. 2000. Soil macroaggregate turnover and microaggregate formation: a mechanism for C sequestration under no-tillage agriculture. Soil Biol. Biochem., 32: 2099-2103.

Takimoto, A., Nair, P.K.R. and Nair, V.D. 2008a. Carbon stock and sequestration potential of traditional and improved agro-forestry systems in the West African Sahel. Agric. Ecosyst. Eviron. 125: 159-166.

Tiessen H., Stewart, J.W.B. and Bettany, J.R. 1982. Cultivation effects on the amounts and concentration of carbon, nitrogen, and phosphorus in grassland soils. Agronomy Journal, 74:831-835.

Venkanna, K., Uttam Kumar Mandal, J. Solomon Raju, K. L. Sharma, Ravikant V. Adake, Pushpanjali, Sanjeeva Reddy, Rahul N. Masane, Venkatravamma and B. PedaBabu. 2014. Carbon stocks in major soil types and land-use systems in semiarid tropical region of southern India. Current Science, VOL. 106, NO. 4, 25 FEBRUARY 2014, pp.604611.

Walkley, A. and C.A. Black. 1934. An examination of the Degtjareff method for determining soil organic matter and a proposed modification of the chromic acid titration method. Soil Sci., 40: 233- 243.

\section{How to cite this article:}

Surya Prabha A. C., K. Arulmani, M. Senthivelu, R. Velumani and Rathnam K. S. 2019. Carbon Sequestration in Dominant Soil Series under Different Land Uses of Tamil Nadu, India. Int.J.Curr.Microbiol.App.Sci. 8(08): 2666-2674. doi: https://doi.org/10.20546/ijcmas.2019.808.309 